\title{
Research on Rights and Relief System of Teachers in Private Colleges
}

\author{
Lei Xu \\ Secretary department \\ Shanghai Jianqiao University \\ Shanghai, China \\ dawn.lei@163.com
}

\author{
Fu-en Cai \\ Secretary department \\ Shanghai Jianqiao University \\ Shanghai, China \\ 14057@gench.edu.cn
}

\begin{abstract}
This paper studies the differences between teachers' rights in private colleges and public colleges and the rights relief of teachers in private colleges. Through legal attribute analysis, interview investigation and international comparative analysis, this paper concluded that the main problems in the teachers' right disputes and right protection mechanism in private colleges include dualization of legal subjects, imperfect legal protection and mere principle and form of the relief of rights. Therefore, it is necessary to perfect the legal guarantee system to improve teachers' rights and the relief system in private colleges, and it is an important way to resolve disputes to set up a collegial system and perfect the school settlement mechanism.
\end{abstract}

Keywords-private colleges, teachers' rights, legal relation, relief system

\section{INTRODUCTION}

The case that the woman teacher with cancer was dismissed in Lanzhou Jiaotong University Bowen College in 2016 has aroused widespread social concern about the rights and relief system of teachers in private colleges. Recently, the author has investigated several typical private universities in Shanghai and collected a series of disputes on the rights and interests between teachers and schools. For example, a private university A selected and sent its outstanding graduates to Peking University, Tsinghua University and other famous universities for directed education in order to cultivate the school faculty, and detained the graduation certificates to make the trained teachers perform the service commitment, and then some teachers had disputes with the school due to dismission. Meanwhile, another teacher of the school was dismissed because he didn't catch the cheating students when monitoring the examination and then had labor relation disputes. In a private university B in Shanghai, a counselor suffered joint report due to the strict check of the class attendance of students in his class, and then was transferred from the teacher post to the logistics post, while the teacher won the honorary title of national outstanding counselor. From the interview with a retired professor as the former secretary of the party committee in a private university in Shanghai, we learnt that the school has accepted several complaints each year in terms of teacher recruitment, teacher dismissal, title promotion, bonus allocation, and teacher training. Such cases widely exist in private colleges, some teachers choose different ways for dispute relief, and

This research was financially supported by the education law talent training program of Shanghai, 2017. more teachers choose to forbear due to various worries.

To guarantee the right subject to enjoy and enforce the right, it is necessary to establish the mechanism of effective relief after the violation of the legitimate rights. No remedy, no right. The spirit of rule of law is not only reflected in the preprotection of rights, but also reflected in the post-relief of rights It is an indispensible link for schools to promote the school running by law, properly safeguard the rights of teachers, and realize the rule of law in school management to establish and improve a mechanism for teacher right relief with legitimacy and rationality.

\section{ANALYSIS OF LEGAL ATtRIBUTE OF TEACHERS' RIGHTS IN PRIVATE COLLEGES}

\section{A. Particularity of teachers' rights in private colleges}

Teachers Law applies to teachers in public universities and is also applicable to teachers in private colleges. Law of the People's Republic of China on Promotion of Privately-run Schools clearly defined in the chapter of "Teachers and Educatees", "teachers and educates of privately-run schools shall enjoy equal legal status as the teachers and eductatees of government-run schools shall." Private college teachers enjoy the equal legal status as the public college teachers, theoretically determining that private university teachers have the same rights as public university teachers.

In October, 1998, the State Council promulgated Interim Regulations on Registration Administration of Private Nonenterprise Units, which defined the private non-enterprise units as enterprises, institutions, social organizations and other social forces as well as the social organizations that are run by individual citizens who use non-state-owned assets to engage in non-profit social service activities. As a result, private colleges have been labeled as "private non-enterprise units", which are essentially classified into the category of business management. Compared to public colleges, private colleges have no administrative level, and their social status is not even as good as that of a state-owned enterprise or a public middle school.

Therefore, although Law of the People's Republic of China on Promotion of Privately-run Schools stipulated that teaching staff of privately-run schools shall enjoy equal legal status as the teaching staff of government-run schools shall, private 
college teachers always belong to the supernumerary staff, and their wages and social security benefits cannot enjoy the public university teachers' standards for career preparation due to the subject positioning of "private non-enterprise units". Similarly in imparting knowledge and educating people, they have relatively lower salary and benefits when they are teaching in school, but it is more significant in the differences between them and the personnel in public colleges and other institutions in pension after retirement. Generally speaking, the particularity of teachers' rights in private colleges is embodied in the following two aspects. On the one hand, as far as the right to remuneration is concerned, the salary and welfare benefits of private college teachers are generally lower than those of public college teachers. On the other hand, private university teachers have some flexibility advantages in retirement age, post-employment options after retirement and bonus allocation.

\section{B. Problems of teachers' rights in private colleges}

Compared to the public colleges, the teachers of the private colleges have "the same work with different remuneration", which is the first right issue. The difference of remuneration mainly reflects the unequal rights of the teachers in private and public universities. In addition, there are also implicit rights missing in the right of education and development.

In terms of the rights of education, the enforcement of the right of education is free, and teachers have the right to independently choose the teaching contents and methods in accordance with the school's positioning and the professional training objectives without violating the laws and regulations. Freedom often drives innovation. Many masters of the Republic of China have different teaching styles, and Southwest Associated University didn't stipulate strict teaching content and methods, which does not affect the cultivation of a large number of outstanding talents. To determine the right attribute of the right to education is of great significance to cultivate the creativity of teachers, especially college teachers, and the creative talents in colleges. As there are no fixed teaching methods, the enforcement of the right to education has individual characteristics. The flexibility of private colleges tends to be represented as certain randomness, and their administrative departments have too many restrictions on the teaching process, thereby forming certain obstacles to the independent exercise of teachers' rights to education. The spirit of university includes academic freedom, academic democracy and educational innovation. While the management institution emphasizes standardization, it should leave some space for the autonomy of teachers. Compared with public colleges, the relative instability of labor relations in private colleges tend to make teachers' status of the workers more vulnerable, and the normalization is prone to eroding the free exercise of the right to education, resulting in infringement of teachers' right of education.

With regard to the right to development, the public college teachers are undoubtedly equipped with better academic research environment. Under the financial support, the disciplines tend to have more influential leaders in the field and teams of stronger research capacities, so that it is easier for teachers to obtain training opportunities, declare high-level projects and obtain personal development. Private college teachers have heavy teaching tasks. And in labor relations, schools invest less in the teachers' personal development as a management party, and teachers have limited development in discipline research and teaching abilities, and their right to development is difficult to be guaranteed. On the other hand, many cases show that after private colleges invest in cultivating specific teachers, the teachers tend to seek for greater personal development while their abilities are continuously promoted, so that they will dissolve the contractual relationship of labor with the school, which will damage the school's interests, and then further influence the enthusiasm of the school to protect teachers' right to development.

\section{MAIN PROBLEMS IN THE MECHANISM FOR RIGHTS DISPUTES AND PROTECTION OF RIGHTS AND INTERESTS OF PRIVATE COLLEGE TEACHERS}

\section{A. Dualization of legal subject and imperfect legal guarantee}

In the world, the United States, Japan, Taiwan, China and other regions have introduced legislation to adopt a binary pattern on teachers in public and private colleges respectively. For example, Japan, a model of the educational legal system worldwide, determines the nature of public college teachers as educational civil servants, and formulated Special law on Education Civil Servants. Moreover, there are perfect department laws for private schools in Japan, including the fundamental law of private schools Private School Law and Rules for the Enforcement of Private School Law and other separate regulations, to establish the equal legal status of private schools and determine the private school teachers' rights.

China's public and private teachers are also subject to the binary legislative model. As mentioned earlier, there are problems of unequal rights between the two subjects. The main special law of establishing the rights of the private colleges and teachers in China is Law of the People's Republic of China on Promotion of Privately-run Schools, while the provisions of the law on the status and rights of teachers are mostly principled and lack practical guarantee. There are blank areas with a lack of law and no statutes to apply in right determination and protection. For example, teachers have relatively lower income in private colleges, and especially the dual system of retirement results in significant differences in the pension between the private and public teachers. In this regard, many regions provide wage subsidies to eligible teachers in private colleges through local regulations or government regulations, or policy documents, and the local education commissions have issued special fund support and related policies for the annuity as a supplement to the pension. However, in the survey, it was found that most private colleges dare not or are not willing to define the annuity system as collective contract terms because of the flexibility and changeability of policies. Even if the collective contract of some universities involves the annuity clause, it is only the principle stipulation that the school sets up the annuity system 
according to the relevant regulations, or "the school pays the annuity for the staff according to the policy of the education commission". As a matter of fact, if a teacher leaves his job and even leaves school after a long period of service, his annuity on the specialized personal account of the former unit after retirement can hardly meet the procedural requirement.

In 2012, the Ministry of Education issued a notice of annual key points for work, which proposed "issuing policy documents to promote the development of private education, cleaning up and correcting all types of discriminatory policies for private schools”, admitting the deficiencies and differences at the institutional level and reserving space for the perfection of the system. The law itself is a question of rationality and the outcome of the game of interest, and its formulation is a process to give consideration to compromise and interests and the content and procedure all have the problem of rationality. As the basic law of China's private education, Law of the People's Republic of China on Promotion of Privately-run Schools has a long process of revision, but there are still deficiencies in the right protection and relief systems of private teachers through the game and balance of interests of all parties.

\section{B. Right relief becomes a mere principle and form}

The relevant legal systems in different countries have different degrees of protection for teachers' rights to relieve, but they tend to affirm, recognize and strengthen the protection. Japan, the United States, Taiwan, China and other countries and regions are based on different subjects of public and private teachers to carry out different safeguards for their rights relief, and apply different legal norms and procedures. Worker's right to safeguard legal rights is called dispute right in Taiwan area of China. As one of the three labor rights, the dispute right has the basic attribute of the constitution, belonging to the important rights and interests in collective labor relations. A teacher belongs to a worker of a specific occupational identity, and the Taiwan region has a clear legal provision for his right to dispute. It is perfect in the system of teachers' right relief and protection of rights and interests in public and private universities in Taiwan, and there are definite legal provisions in the aspects of appointment, promotion and dismissal. Unlike the relatively random dismissal in mainland private colleges, the appointment must pass three reviews at three levels in the department, school and college, and the dismissal must comply with strict conditions (sufficient to prove that one is unable to be competent for the job) and procedures. It was found from the survey that a teacher in a private university in Taiwan was appointed through the three reviews at three levels, but then the school was reluctant to continue to engage him, and then adjusted his post due to the strict policy system, while the teacher filed a complaint. All of the schools in Taiwan have set up a teacher complaint commission with a wide range of complaints to accept, including dismissal, blocked promotion and other major disputes on rights and interests, as well as infringement of gender equality and other rights, such as sexual harassment and other civil rights disputes. In Taiwan, the procedures of teachers' complaints are usually to first appeal to the school and then appeal to the ministry of education if the client refuses to accept appeal results. Besides, the client can also appeal to the ministry of education directly, and then the ministry of education sends a letter to the school to require the school to handle and follow up the situation. Private schools in Taiwan have a powerful teacher union, and teachers may appeal to the teacher union in addition to appealing to the appeal committee of the school. In the survey, it was found that many teachers were more inclined to appeal directly to the ministry of education by letters after the dispute.

Currently, it is not significant in the effect of right relief for teachers in China, especially private teachers, the reasons for which mainly include the lack of legal protection, the client's insufficient awareness to safeguard legal rights, insufficient capacities to safeguard legal rights, and inadequate independence and validity for collective organizations to participate in safeguarding rights. On the one hand, teachers in private colleges have weak consciousness of safeguarding the rights. On the other hand, it is not yet mature in the legal culture environment of actively safeguarding rights, and teachers tend to worry that relevant data will be recorded in the file after the dismissal, or that it may lead to adverse social impact due to the litigation or administrative appeal, leading to difficulties in seeking new jobs, so that they may give the right of claim and offer to resign voluntarily.

At the theoretical level, teachers' rights relief path includes the campus mediation (or school appeal), administrative appeal to administrative departments in charge of education or the government, arbitration to labor dispute arbitration committee and litigation to the court. The relevant laws and regulations have affirmed the teachers' right to dispute relief, but the substantive significance is not significant for the private college teachers. Clause 1 of Article 39 in Teachers Law prescribed that "If the school or other educational institution violates a teacher' lawful rights and interests or the teacher refuses to accept the treatment made by the school or other educational institution, he may lodge a complaint with the administrative department for education" . After receiving the complaint, the administrative department of education should deal with it. Clause 2 stipulated that "If the teacher believes that the relevant administrative department of the local people's government violates his rights according to the provisions of this law, he may appeal to the people's government at the same level or the relevant department of people's government at the next higher level, which shall deal with the appeal" . Article 39 of Teachers Law is the main basis of teachers; right to appeal in China, which stipulated the subject of appeal, acceptance items and the subject of acceptance. However, the provisions become a 
mere principle, with a lack of applicability to contractual relationship of labor in private colleges.

In addition, as mentioned above, it is particular in the labor relations between teachers and schools in private colleges. Except for disputes over dismissal, both professional title assessment and rewards and punishments are difficult to be settled through labor dispute arbitration and litigation according to Labor Contract Law.

Compared with the subject of the university, teachers are in a weak position, and the participation of the collective organizations will balance the status of both sides, and increase teachers' right of speech for dispute settlement. Taiwan has comparatively developed legal systems for collective labor, and the theory and practice circles call the right to organize, collective bargaining and strike as "three labor rights" or "the basic right to work". Laborers shall have the right to organize trade unions in accordance with the provisions of the law and, without prejudice to social order and public interests, shall have the right to deal with disputes through collective bargaining through trade unions. As for the right relief mechanism, Britain can be a representative of Europe. It is diversified in British teacher's union organizations, and the teacher unions have their specific goals and their membership requirements, and teachers are subject to equal treatment regardless of the public and the private, while they have to join the different teacher unions according to their background, position and other factors, its member requirements show a weakening trend. In Britain, there are six major teacher union organizations, including National Union of Teachers, Association of Teachers and Lecturers and Professional Association of Teachers, of which National Union of Teachers is the largest in Europe. Its members consist of teachers in public and private schools (no matter teachers obtain teachers' license or they are full-time), while the union is included in the country's major educational institutions and affects legislation of education and teacher employment at the national and local levels. The educational unions in Canada and other countries have also played a significant role, as educational unions often intervene in mediation, complaint, arbitration and litigation in the name of organization in the process of teachers' disputes on rights and the relief of rights and interests.

China's private colleges generally implement the president's responsibility system under the leadership of the board of directors, and the power is relatively concentrated. The members of the teacher unions are mostly the staff, the labor union, related associations and even party committees besides the leaders of the party committee of the school, who mainly play a role as a bridge and link but fail to really balance the school in terms of rights protection. The party committee and teachers' congress fail to play a substantial role in teachers' right relief and dispute settlement on rights and interests as supervision and democratic management institutions. The collective organizations in colleges play a weak role in the maintenance of teachers' rights.

\section{TWO IDEAS OF IMPROVING THE RIGHT RELIEF SYSTEM} OF PRIVATE COLLEGE TEACHERS

\section{A. To improve the legal guarantee system}

There is no doubt that the right to remuneration is the most fundamental right of the worker. In order to stabilize the teaching team and effectively protect teachers' rights, special funding support and related policies for relevant subsidies and pensions can be upgraded to laws under the circumstance of the existing dual retirement system, or the existing local regulations or government rules and regulations can be upgraded to laws to enhance the legal hierarchy and stability. Specific legal norms can refer to those in Taiwan, China. There are four special laws relating to the protection of teachers' rights and the settlement of disputes on rights and interests in private schools in Taiwan, namely, Private School Law, Rules for the Implementation of the Private School Law, Severance Ordinance on Retirement, Compensation and Dismission of Teaching Staff in the School Corporation and Its Private School and Rules for the Implementation of Severance Ordinance on Retirement, Compensation and Dismission of Teaching Staff in the School Corporation and Its Private School, which have made clear, detailed and operable provisions on the nature of private schools, the status of the subject, finance and tax of the school and aids to the school, and the protection of the school's legal status is undoubtedly conducive to the protection of the social status of private school teachers. Moreover, relevant laws have made legal confirmation and protection on teachers' rights in private schools, especially in remuneration, retirement, and dismission treatment. In addition, China should take Law of the People's Republic of China on Promotion of Privatelyrun Schools as the "parent law" , and further introduce other relevant laws and regulations, to enhance the operability of Law of the People's Republic of China on Promotion of Privately-run Schools, and supply the deficiencies of this law, and to form a systematized law and regulation system of private education. China should perfect the substantial legal guarantee system for the rights of teachers in private colleges, and then improve the implementation of the rights and relief procedures.

\section{B. To improve the legal guarantee system}

Based on the reasonable hypothesis that the interests of private college organizers and those of the schools are in the same direction and organizers don't hope the expansion of the influence of labor disputes, private universities in mainland China may, in light of the Taiwan area, set up a practical school appeal committee, which shall be authorized by the school board of directors to ensure its independence. The procedures of the member election are as follows. It should hire another member, who can be recommended various departments of the school or selfrecommended and engage by way of campaign, and then the board of directors should determine the appeal committee. Meanwhile, each department or secondary college must ask 
teachers to participate in the election to ensure extensive representation. Members shall not be dismissed during their term of office. Committee personnel should be re-elected every year, as far as possible to prevent power rent-seeking and interest transfer.

Furthermore, it should increase the independence of the teachers' congress and the labor union to facilitate them to play their roles. According to the experience of some private universities, the democratic specialized committee may be set up under the presidium of teachers' congress to focus on issues about rights protection. It is suggested that the employment committee be set up to deal with special employment, dismissal and other major issues of rights, while other major issues of rights should be also resolved by the corresponding special committees like professional title assessment. By enhancing independence, making clear the specialty and representativeness of the members, and cooperating with the third-party specialized agencies, the role of the school committee on labor (personnel) disputes can be effectively brought into full play.

In UN's International Covenant on Civil and Political Rights that China has signed, Clause One of Article 22 prescribed that "Everyone shall have the right to freedom of association with others, including the right to form and join trade unions for the protection of his interests". Article 84 of UNESCO Recommendation concerning the Status of Teachers suggested that "An appropriate collegial system shall be established to resolve disputes between teachers and employers arising from labor conditions. In the event that the paths and procedures established for this purpose have been exhausted or when the two sides have broken down, the teachers' group shall have the right to take other means which other groups may normally use in order to protect their legitimate interests." Currently, it is difficult for administrative appeals to play a practical role and the scope of litigation filing is restricted. On this basis, the improvement of democratic school management and dispute settlement mechanism is undoubtedly an important path for private universities to establish harmonious employment relationship, dissolve disputes, and reduce the contradiction between education subjects and negative social influence. Moreover, it is also of great benefits to carry out the idea of running the school according to law, to perfect the corporate governance structure, democratic politics construction and construction of the modern university system in private universities.

\section{CONCLUSION}

For a long time, the right of students to receive education has attracted wide attention. Furthermore, we should realize that teachers' right to education and right to dispute and legal interests are also related to the public interest and should not be neglected. Private college teachers are the key to the development of private education, so that they are required to assume more responsibilities and obligations to develop the learning habits of educatees with a weak knowledge base, improve their learning ability, and strive to achieve the training objectives. At present, the imbalance of rights and obligations of teachers in private colleges, the insufficient legal guarantee system for their right relief, and the lack of operability in the guarantee path, will affect teachers' subjective initiative and stability, thereby affecting the development of higher private education in China. Based on the strategy of building a global community, China proposed The Belt and Road to achieve the infrastructure connectivity and seek common development. Infrastructure construction is of great significance, teachers in the private colleges are also an important component of the educational foundation, and the improvement of the legal guarantee for their rights and the relief of rights and interests will surely be beneficial to the personnel training of great craftsmen.

\section{ACKNOWLEDGEMENT}

This research was financially supported by the education law talent training program of Shanghai, 2017.And this paper is the stage achievement of the project of private college teachers and students rights relief system and equity dispute settlement mechanism(Item No.2017JYFXR029).

\section{REFERENCE}

[1] Construction of Legal System of Right Relief for College Teachers and Students. Liu Xiu. Journal of Chongqing Institute of Technology [J]. $2008(03)$

[2] Follow the spirit of the rule of law and build harmonious colleges. Zhang Yongwei. China Electric Power Education [J]. 2010 (12)

[3] Teaching Rights of Teachers. Liu Dongmei. Journal of Henan Normal University [J]. 2014 (11)

[4] Reflections on Improvement of the Right Relief System for University Teachers in China. Liu Yanbo. Heilongjiang Researches on Higher Education [J]. 2012 (03)

[5] Exploration and Enlightenment of Managing Schools according to Law in Xi'an Jiaotong-Liverpool University. Xi Youmin, Zhang Xiaojun. Journal of World Education [J]. 2014 (11)

[6] Formulation and Perfection of University Statutes in the Context of Managing Schools according to Law [J]. Bao Shumei. Intelligence. 2014 (11)

[7] Formulation Principles and Content Elements of Statutes for Higher Vocational Colleges [J]. Xie Ruiqing. Vocational and Technical Education. 2014 (09)

[8] Comprehensive Promotion of Managing Schools according to Law Based on Formulation of University Statutes as the Opportunity [J]. Tian Chengchun, Xie Yunzhi. Journal of Sichuan Normal University (Social Science Edition). 2015 (01)

[9] Chinese Educational Law Review [M]. Educational Science Publishing House. Editor: Lao Kaisheng. 2002

[10] Discussion on Teachers' Consultation Rights and Rights to Strike in the Public Sector from the Perspective of Three Labor Rights [M]. Journal of Social Sciences and Philosophy, 1999 